\title{
Bacteroides disiens sp. nov. and Bacteroides bivius sp. nov. from Human Clinical Infections
}

\author{
LILLIAN V. HOLDEMAN AND J. L. JOHNSON
}

Anaerobe Laboratory, College of Agriculture and Life Sciences, Virginia Polytechnic Institute and State University, Blacksburg, Virginia 24061

Bacteroides disiens sp. nov, and Bacteroides bivius sp. nov., both isolated from human clinical specimens, are described. They are species of obligately anaerobic, nonsporeforming, nonmotile, nonpigmenting, gram-negative rods that produce succinic and acetic acids (often with traces of isobutyric, isovaleric, and lactic acids) from peptone-yeast-glucose cultures. Gelatin, milk, casein, and meat are digested. Glucose, maltose, and starch, but not sucrose, are fermented. Most strains of $B$. bivius also ferment lactose. Hemin is required for growth. Strains of these species are phenotypically similar to those of $B$. melaninogenicus subsp. intermedius except that they do not form pigmented colonies. However, they do not show a high level of deoxyribonucleic acid/deoxyribonucleic acid homology with B. melaninogenicus subsp. intermedius or with each other. ATCC 29426 $(=$ VPI 8057) is designated the type strain of B. disiens, and ATCC 29303 (= VPI 6822 ) is designated the type strain of $B$. bivius.

During the past 5 years, our reference laboratory has received more than 50 similar isolates, mostly from human clinical infections, that were phenotypically similar to strains of Bacteroides melaninogenicus subsp. intermedius except that they never produced dark brown or black colonies. Phenotypically, these isolates were separated into two groups differentiated by the inability of one of the groups to ferment lactose. These groups have been previously described and referred to as Bacteroides Group I and Bacteroides Group PS, respectively, in the October 1974 and February 1976 issues of the $A n$ aerobe Newsletter (VPI Anaerobe Laboratory, Blacksburg, Va.). The Bacteroides Group I and Bacteroides Group PS designations have also been used by Lambe and colleagues $(10,11)$ in recent reports.

Because of the close phenotypic resemblance of members of the two groups to B. melaninogenicus subsp. intermedius and the phenotypic similarity between the two groups, we did not know whether these groups represented two new species, one new species, or nonpigmenting variants of B. melaninogenicus subsp. intermedius. However, deoxyribonucleic acid (DNA)/DNA homology studies presented here have shown that the two groups are distinct.

One of the major characteristics of these two groups is that they have both saccharolytic and proteolytic properties, and this is reflected in the derivation of the proposed specific epithets. We propose the name Bacteroides disiens sp. nov., with ATCC 29426 (= VPI 8057) as the type strain, for the group formerly designated
Bacteroides Group I and the name Bacteroides bivius sp. nov., with ATCC 29303 (= VPI 6822) as the type strain, for the group formerly designated Bacteroides Group PS.

\section{MATERIALS AND METHODS}

Bacterial strains. The sources of the 11 strains of $B$. disiens, the 14 strains of $B$. bivius, and of five phenotypically similar strains used in this study are given in Table 1 . In addition, VPI 4197 (= Finegold $\mathrm{B} 422 \rightarrow \mathrm{VPI} \rightarrow \mathrm{ATCC} 25611)$ and VPI $8944(\leftarrow$ NCTC 9336) were used to determine the DNA relatedness of the study strains to $B$. melaninogenicus subsp. intermedius. Both VPI 4197 and 8944 had the phenotypic characteristics of $B$. melaninogenicus subsp. intermedius (6).

Culture media and methods. Cultures of the strains studied were characterized using media and methods described previously (6). Prereduced media (6) were gassed (with oxygen-free carbon dioxide or with nitrogen [90\%]-carbon dioxide [10\%] passed over hot copper to remove oxygen) while they were being inoculated. In addition to specific substrates, all media, unless otherwise stated, contained (per $100 \mathrm{ml}$ ) $0.5 \mathrm{~g}$ of peptone (Difco), $0.5 \mathrm{~g}$ of Trypticase (Baltimore Biological Laboratories), $1.0 \mathrm{~g}$ of yeast extract (Difco), and $0.5 \mathrm{mg}$ of crystalline equine hemin (Sigma). Unless otherwise specified, the concentration of vitamin $\mathrm{K}_{1}$ (Sigma V-3501) was $0.17 \mathrm{nl} / \mathrm{ml}$ (about $0.17 \mu \mathrm{g} / \mathrm{ml}$ ) in broth and $1.0 \mathrm{nl} / \mathrm{ml}$ (about $1 \mu \mathrm{g} / \mathrm{ml}$ ) in solid media.

The effect of hemin on growth and fermentation products was tested in the peptone-yeast-glucosehemin (PYGH) medium described above with $1 \mu \mathrm{g}$ of vitamin $K_{1}$ per $\mathrm{ml}$ and in the same medium that was hemin-free (PYG-HF). In preparing PYG-HF medium, all glassware was cleaned in a Wilt glassware cleaning oven (Laboratory Glass Blowing, Inc., Lathan, N.Y.) by heating at $450^{\circ} \mathrm{C}$ for $4 \mathrm{~h}$. All rubber 
TABLE 1. Strains Studied

\begin{tabular}{|c|c|c|c|c|}
\hline $\begin{array}{l}\text { VPI } \\
\text { no. }\end{array}$ & $\begin{array}{l}\text { Isolated or } \\
\text { referred by }\end{array}$ & $\begin{array}{l}\text { Sender } \\
\text { no. }\end{array}$ & $\begin{array}{c}\text { Sex of } \\
\text { patient }\end{array}$ & Type or source of specimen (comments) \\
\hline \multicolumn{5}{|c|}{ Bacteroides disiens } \\
\hline 8057 & DWL & $1304-72 B$ & $\mathrm{~F}$ & Bartholin abscess (leukemia) \\
\hline 7617 & DWL & $339-72 \mathrm{~A}$ & F & cervical swab (dilation and curettage) \\
\hline 7852 & DWL & $894-72 \mathrm{~A}$ & M & draining stomach infusion (cancer of esophagus) \\
\hline 7874 & DWL & $860-72 G$ & $\mathrm{~F}$ & pelvic abscess \\
\hline 8573 & DWL & $343-73 \mathrm{C}$ & $\mathrm{F}$ & vaginal swab (cancer of cervix) \\
\hline 9061 & DWL & $1314-73 \mathrm{~A}$ & $\mathrm{~F}$ & fluids ( 2 weeks post-operative hysterectomy) \\
\hline 9495 & DWL & $709-74 \mathrm{D}$ & M & perineum \\
\hline 9627 & DWL & $854-74 \mathrm{~A}$ & $\mathrm{~F}$ & groin (post-operative adrenalectomy) \\
\hline 9629 & DWL & $873-74 B$ & M & penile ulcer drainage \\
\hline 10723 & DWL & $1393-75 \mathrm{D}$ & M & scrotal cyst drainage \\
\hline 10798 & DWL & $1751-75 B$ & M & penis wound \\
\hline \multicolumn{5}{|c|}{ Bacteroides bivius } \\
\hline 6822 & DB & $653 \mathrm{C}$ & $\mathbf{F}$ & endometrium \\
\hline 5965 & DWL & $813-70 \mathrm{~A}$ & $\mathrm{~F}$ & chest fluid \\
\hline 5966 & DWL & $826-70 \mathrm{~A}$ & $M$ & penis drainage \\
\hline 6318 & VPI & - & $\mathrm{F}$ & cervico-vaginal swab (clinically healthy) \\
\hline 7962 & DWL & $1072-72$ & $\mathrm{~F}$ & breast abscess \\
\hline 8478 & DWL & $195-73 B$ & $\mathrm{~F}$ & transabdominal hysterectomy \\
\hline 8587 & $J M R$ & - & $\mathrm{F}$ & blood (septic abortion) \\
\hline 9346 & DWL & $374-74 \mathrm{C}$ & M & urethral discharge \\
\hline 9498 & E.O'D. & 6444 & $\mathrm{~F}$ & blood \\
\hline 9725 & DWL & $1005-74 \mathrm{D}$ & M & cyst drainage \\
\hline 10307 & DWL & $492-75 B$ & $\mathrm{~F}$ & infected thigh wound \\
\hline 10385 & DWL & $588-75 \mathrm{C}$ & $\mathrm{F}$ & peritoneal fluid (pelvic inflammatory disease) \\
\hline 10662 & DMN & 751510 & $\mathrm{~F}$ & vaginal discharge \\
\hline 10752 & DMN & 752195 & $\mathrm{~F}$ & post-cesarean section \\
\hline \multicolumn{5}{|c|}{ Other Strains } \\
\hline 7620 & DWL & $404-72 B$ & $\mathrm{~F}$ & anal fistula \\
\hline 9447 & DWL & - & $\mathrm{F}$ & cervical tumor \\
\hline 9754 & DWL & $1153-74 \mathrm{~A}$ & $\mathrm{~F}$ & breast (recurrent breast cancer) \\
\hline 10709 & VPI & - & $\mathrm{F}$ & bone fragment (osteomyelitis of canine jaw) \\
\hline 10879 & PW & 74505 & - & brain abscess \\
\hline
\end{tabular}

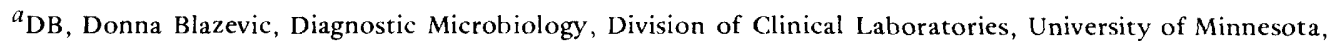
Minneapolis, Minnesota; DMN, Dianne M. Norris, National Health Institute, Wellington, New Zealand, DWL, Dwight W. Lambe, Jr., Laboratory of Pathology, Northeast Deaconess Hospital, Boston, Massachusetts; E.O'D., Ed O'Donnell, Medical College of Ohio, Toledo; JMR, James M. Reid, Memorial Medical Center, Savannah, Georgia; PW, Palma Wideman, Wadsworth VA Hospital, Los Angeles, California; VPI, our laboratory.

$b_{\mathrm{F}}$, female; $M$, male; - , sex not indicated with information received

stoppers and rubber tubing used were soaked in a $1 \%$ solution of 7X (Linbro Scientific, Inc., Hamden, N.Y.) overnight and then rinsed, first with tap water and then with distilled water. A separate medium-dispensing system, through which hemin-containing medium never passed, was used in dispensing the hemin-free medium. We found that these special cleaning procedures were necessary because trace amounts of residual hemin on glassware or rubber stoppers cleaned in the usual manner permitted slight growth of the organisms. To determine growth in hemin-free medium, cultures were serially transferred at least three times 
in PYGH medium and in PYG-HF medium. Serial transfers were made with about $0.15 \mathrm{ml}$ of inoculum into $5 \mathrm{ml}$ of medium. The original inoculum was from an overnight culture in chopped meat-carbohydrate (CMC) medium (6). Serial transfers were made after overnight incubation from cultures that had $2+$ growth (optical density $=$ at least 0.15 ) or greater; cultures with lesser growth were incubated another $24 \mathrm{~h}$ and then transferred. Optical density readings were determined in a Spectronic 20 (Bausch and Lomb) spectrophotometer at a wavelength of $640 \mathrm{~nm}$.

Fatty acids produced were analyzed as previously described (6) using a Dohrmann Anaerobic Bacteriology Analyzer gas chromatograph and a Hewlett-Packard $3380 \mathrm{~A}$ integrator recorder. The column packing was Supelco 1000 , the oven temperature was $130^{\circ} \mathrm{C}$, and the carrier gas was $120 \mathrm{~cm}^{3}$ of helium per min. The analytical method for hydrogen was previously described (15).

Colonies on supplemented Difco brain heart infusion (BHIA)-5\% rabbit blood agar (6) and on Pfizer brucella (Albimi) agar with vitamin $\mathrm{K}_{1}$, hemin, and $5 \%$ laked (hemolyzed) rabbit blood were examined for pigmentation and for fluorescence under long-wave ultraviolet light after plates had been incubated for 40 to $48 \mathrm{~h}$ in anaerobic GasPak (BBL) jars in an atmosphere of $90 \%$ hydrogen- $10 \%$ carbon dioxide. After the initial examination for pigmentation, plates were reincubated anaerobically for an additional 3 to 5 days and then reexamined for pigmenting colonies. Colonies in anaerobic streak tubes on supplemented BHIA with laked rabbit blood were also examined for pigmentation. Colonies in laked blood streak tubes were held for 14 days before recording absence of pigmentation.

The broth disk test of Wilkins and Thiel (16) was used to determine susceptibility to antimicrobial agents.

DNA isolation. Methods used for the isolation of DNA have been described $(3,13)$. High-molecularweight DNA for immobilizing on nitrocellulose filters was isolated from cells suspended in $0.15 \mathrm{M} \mathrm{NaCl}-0.01$ ethylenediaminetetraacetic acid buffer, pH 8.0 (13). The cells were treated with $1 \%$ sodium lauryl sulfate and disrupted by shaking with glass beads (8). After a preliminary extraction with chromatography-grade phenol, the DNA was isolated by the method of Marmur (13). Preparations of competitor DNA and labeled DNA were isolated using a hydroxyapatite procedure (J. L. Johnson, unpublished data).

Determination of $G+C$ content and DNA/DNA homology methods. The moles percent guanineplus-cytosine $(\mathrm{G}+\mathrm{C})$ values of the DNA preparations were determined by the thermal melting point $\left(T_{m}\right)$ method (14) by use of a Gilford 2400 automatic recording spectrophotometer equipped with a model 2527 thermal programmer. DNA from Escherichia coli $\mathrm{B}$ was included in each set as a standard.

The methods used for immobilizing DNA on nitrocellulose filters and for doing the DNA competition experiments have been described $(3,9)$. For some competitor DNA preparations, we were unable to obtain the desired $1.5 \mathrm{mg} / \mathrm{ml}$ concentration of DNA. In competition experiments with these preparations, the concentration of the homologous competitor DNA was lowered so that the comparisons were made at the same point on the competition curve.

\section{RESULTS AND DISCUSSION}

The Group I ( $B$. disiens) and Group PS ( $B$. bivius) strains were compared by DNA homology. Strains VPI 8057 (= ATCC 29426) and VPI 6822 (= ATCC 29303) were used as the reference strains. The results are shown in Table 2 . Although the DNA preparations had the same $\mathrm{G}+\mathrm{C}$ contents, two rather homogeneous DNA homology groups were obtained. Ten strains studied had DNA with 82 to $98 \%$ homology with DNA of strain 8057 , and 13 strains had DNA with 83 to $96 \%$ homology with DNA of strain 6822. The levels of DNA homology found between DNA preparations of the two groups are in a range that is usually considered to constitute different species (7). Also included in Table 2 are the results from five strains that were similar, in many phenotypic characteristics, to the other strains. The $\mathrm{G}+\mathrm{C}$ values were different for these five strains, and all had little or no DNA homology with the two reference strains used, indicating that these five strains belong to one or more other species.

Because strains of $B$. disiens and $B$. bivius had phenotypic characteristics similar to those described for B. melaninogenicus subsp. intermedius except that they did not form colonies with brown or black pigment on blood agar, the DNA relationships between the reference strains of $B$. bivius and $B$. disiens and two strains with characteristics as described for B. melaninogen icus subsp. intermedius (6) were investigated. The results are shown in Table 3. There was negligible DNA homology between reference DNAs of $B$. bivius and $B$. disiens and DNAs of the two strains with characteristics of B. melaninogenicus subsp. intermedius, which indicates that these strains are not merely nonpigmenting variants of $B$. melaninogenicus. The two strains with phenotypic characteristics of B. melaninogenicus subsp. intermedius had only low levels of DNA homology with each other. The DNA homologies among strains of $B$. melaninogenicus are currently being investigated. Preliminary results indicate that the group may be heterogeneous, but any taxonomic recommendations would be premature at this time.

The strains with a high level of DNA relatedness to reference DNA of VPI 8057 are genetically distinct from those which show high DNA relatedness to strain VPI 6822 as well as from similar organisms. Because the strains which show a high degree of relatedness to VPI 8057 and those which show a high degree of related- 
TABLE 2. DNA homologies among strains of Bacteroides disiens, B. bivius, and some unidentified strains

${ }^{a} \mathrm{G}+\mathrm{C}$, Guanine + cytosine.

Table 3. Percent DNA/DNA homologies among Bacteroides disiens, B. bivius, and B. melaninogenicus subsp. intermedius

\begin{tabular}{|c|c|c|c|c|c|c|}
\hline \multicolumn{3}{|c|}{ Competitor DNA } & \multicolumn{4}{|c|}{ Reference DNA } \\
\hline \multirow{2}{*}{ Species or group } & \multirow{2}{*}{$\begin{array}{l}\text { VPI strain } \\
\text { no. }\end{array}$} & \multirow{2}{*}{$\begin{array}{l}\mathrm{G}+\mathrm{C} \\
(\mathrm{mol} \%)\end{array}$} & \multirow{2}{*}{$\begin{array}{l}\text { B. disiens } \\
8057\end{array}$} & \multirow{2}{*}{$\begin{array}{l}\text { B. bivius } \\
\quad 6822\end{array}$} & \multicolumn{2}{|c|}{$\begin{array}{l}\text { B. melaninogenicus subsp } \\
\text { intermedius }\end{array}$} \\
\hline & & & & & 8944 & 4197 \\
\hline B. disiens & 8057 & 40 & 100 & 25 & 7 & 21 \\
\hline B. bivius & 6822 & 40 & 26 & 100 & 3 & 4 \\
\hline $\begin{array}{l}\text { B. melaninogenicus subsp. } \\
\text { intermedius }\end{array}$ & 8944 & 42 & 15 & 12 & 100 & 42 \\
\hline $\begin{array}{l}\text { B. melaninogenicus subsp. } \\
\text { intermedius }\end{array}$ & 4197 & 44 & 34 & 3 & 30 & 100 \\
\hline
\end{tabular}

ness to VPI 6822 are obligately anaerobic, nonmotile, gram-negative rods that produce succinic and acetic acids, usually with isovaleric and isobutyric acids, they are placed in the genus $\mathrm{Bac}$ teroides (5) as two new species, descriptions of which follow.

Bacteroides disiens sp. n. (di'si.ens L part. adj. disiens going in two different directions; intended to refer to the fact that the organism is both saccharolytic and proteolytic). This species comprises obligately anaerobic, nonmotile, nonsporeforming, nonpigmenting, gram-negative rods. Gram stains of pure cultures in broth or of single colonies from agar show predominantly short gram-negative rods in pairs or, occasionally, short chains with longer rods (Fig. 1). The longer rods occur both singly and in chains with the short rods. Since the variation in cell length often makes one think that the culture is mixed, the observation of short and long rods in the same chain can be a guide to judging the purity of a culture.

Cells of strain VPI 8057 were $0.8 \mu \mathrm{m}$ wide and 2.0 to $8.2 \mu \mathrm{m}$ long. The average minimum and maximum cell dimensions of five strains measured were 0.6 to $0.9 \mu \mathrm{m}$ in width and 2.0 to 7.4 $\mu \mathrm{m}$ in length. No flagella were detected with Leifson flagella stain.

Cultures did not survive heating at $80^{\circ} \mathrm{C}$ for $10 \mathrm{~min}$.

Colonies. After incubation for 1 to 2 days on BHIA or BHIA-laked blood streak tubes or on freshly prepared brucella-laked blood agar plates incubated for 2 days, colonies were minute to $2.0 \mathrm{~mm}$ in diameter, circular, entire, convex, translucent to opaque, smooth, shiny, and white. 
There usually was no hemolysis on blood agar plates; occasionally a slight greening or indefinite hemolysis was observed, usually in the area of confluent growth.

No brown or black pigmentation was observed in colonies on BHIA-laked blood streak tubes or on laked blood agar plates. Colonies of VPI 9627 and 10723, but not of ATCC 29426, showed light orange to pink fluorescence on blood agar plates.

There was no growth on blood agar plates incubated in a candle-extinction jar or in an aerobic atmosphere.

Cultural characteristics. Cultures in prereduced peptone-yeast broth were moderately turbid, sometimes with a slight, smooth sediment. Growth was somewhat enhanced in broth with a fermentable carbohydrate, and these cultures were turbid with a smooth (sometimes granular or flocculent) sediment. Cultures grew well in CMC broth (6).

Best growth was at $37^{\circ} \mathrm{C}$, although some strains grew to some extent at $25^{\circ} \mathrm{C}$ and $45^{\circ} \mathrm{C}$.

After good growth was observed in PYG cultures, usually after incubation for 1 day, the $\mathrm{pH}$ of the culture was 4.9 to 5.2 . The $\mathrm{pH}$ of cultures in broth media without fermentable carbohydrate was often 5.9 to 6.1 ; therefore, a $\mathrm{pH}$ of 5.7 or above was interpreted as no fermentation, a $\mathrm{pH}$ between 5.5 and 5.7 was interpreted as weak fermentation, and a $\mathrm{pH}$ below 5.5 was interpreted as strong fermentation. In general, the terminal $\mathrm{pH}$ of cultures in broth media containing fermentable carbohydrates was the same in an atmosphere of $90 \%$ nitrogen- $10 \%$ carbon dioxide as it was in $100 \%$ carbon dioxide.

Biochemical reactions. Some biochemical reactions of strain ATCC 29426 and of other

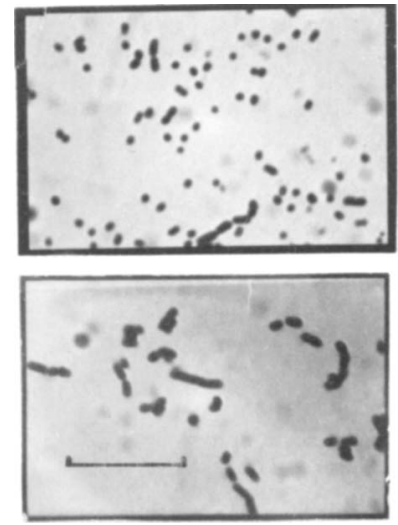

FIG. 1. Bacteroides disiens ATCC 29426. Left, Cells from 24-h-old peptone-yeast broth culture. Right, Cells from 24-h-old peptone-yeast-glucose broth culture. Bar represents $10 \mu \mathrm{m}$. strains of this species included in this study are given in Table 4. Cultures that had been transferred several times in the laboratory digested gelatin, milk, and meat in 1 to 3 days, but newly isolated strains often did not show evidence of digesting milk and meat until after incubation for 10 to 14 days. Casein digestion, however, was apparent in $48 \mathrm{~h}$, even with freshly isolated strains.

Strains grew very poorly, if at all, in PYG$20 \%$ bile broth or in PYG-6.5\% $\mathrm{NaCl}$ broth.

Fermentation products. The fermentation acids (in average milliequivalents per $100 \mathrm{ml}$ ) from PYG culture were succinic (3.5) and acetic (1.3), usually with traces of isovaleric and isobutyric and sometimes with small amounts of formic, propionic, or lactic acids. Products from CMC cultures were succinic $(12.7 \mathrm{meq} / 100 \mathrm{ml})$, and acetic $(2.3 \mathrm{meq} / 100 \mathrm{ml})$ acids, usually with traces of isovaleric and isobutyric acids and sometimes with small amounts of propionic, butyric, and lactic acids.

Lactate and pyruvate were not utilized.

Hydrogen was not produced and there were no, or only a few, gas bubbles in PYG agar deep cultures.

Susceptibility to antimicrobial agents. All 11 strains were susceptible to chloramphenicol $(12 \mu \mathrm{g} / \mathrm{ml})$, clindamycin $(1.6$ and $3.2 \mu \mathrm{g} / \mathrm{ml})$, erythromycin $(3 \mu \mathrm{g} / \mathrm{ml})$, and tetracycline $(6$ $\mu \mathrm{g} / \mathrm{ml})$. Strain VPI 8057 and six other strains were susceptible and four strains were resistant to penicillin $(2 \mathrm{U} / \mathrm{ml})$.

$\mathbf{G}+\mathbf{C}$ content. The $\mathrm{G}+\mathrm{C}$ content of the DNA was $40 \mathrm{~mol} \%$ for strain ATCC 29426 (= VPI $8057)$ and 40 or $42 \mathrm{~mol} \%$ for the other three strains tested (Table 2).

Type strain. ATCC 29426 (= VPI 8057 [D. W. Lambe, Jr., EUH no. N-1304-72B, isolated from Bartholin abscess]).

Bacteroides bivius sp. n. (bi'vi.us L. adj. bivius having two ways, pertaining to the saccharolytic and proteolytic activities of the species). This species comprises obligately anaerobic, nonmotile, nonsporeforming, gram-negative rods. Gram stains of pure cultures in broth or of single colonies from agar show predominantly short, gram-negative rods in pairs or short chains with longer rods only occasionally seen (Fig. 2). In fact, in some cultures the cells may be so short and the short cells so numerous that one is inclined to think that one has a culture of gramnegative cocci. Cells of strain VPI 6822 ranged from 0.6 to $1.3 \mu \mathrm{m}$ in width and from 1.3 to 2.8 $\mu \mathrm{m}$ in length. The average minimum and maximum cell dimensions of all strains measured were 0.7 to $1.2 \mu \mathrm{m}$ in width and 1.3 to $4.6 \mu \mathrm{m}$ in length. No flagella were detected with Leifson 
flagella stain. Cultures did not survive heating at $80^{\circ} \mathrm{C}$ for $10 \mathrm{~min}$.

Colonies. After incubation for 1 to 2 days on BHIA or BHIA-laked blood streak tubes or for 2 days on freshly prepared brucella-laked blood agar, colonies were 0.5 to $2.0 \mathrm{~mm}$ in diameter, circular, entire to slightly erose, convex, translucent to semiopaque, smooth, and glistening. Colonies of VPI 7962, 8587, 9498, and 9725, but not of ATCC 29303, showed light orange to pink fluorescence under long-wave ultraviolet light. Slight greening or an indefinite hemolysis often was apparent on blood agar plates. No black or brown pigmentation was observed in colonies on BHIA-laked blood streak tubes incubated for 14 days or on laked blood agar plates incubated for 5 days in an anaerobe jar.

There was no growth on blood agar plates incubated in a candle-extinction jar or in an aerobic atmosphere.

Cultural characteristics. Cultures in prereduced peptone-yeast extract broth were turbid with moderate sediment. Growth was somewhat enhanced in broth with a fermentable carbohydrate, and these cultures were turbid with a smooth (sometimes slightly stringy) sediment. Best growth was reliably obtained at $37^{\circ} \mathrm{C}$. Some strains also grew maximally at $30^{\circ} \mathrm{C}$. Some strains grew moderately well at $45^{\circ} \mathrm{C}$; no strain grew at $25^{\circ} \mathrm{C}$.

After good growth was observed in PYG cultures ( 1 to 2 days), the $\mathrm{pH}$ was 4.7 to 5.0. Fructose was often fermented less well (more slowly and to only $\mathrm{pH} 5.0$ to 5.7 ) than the other fermentable carbohydrates. The $\mathrm{pH}$ of cultures in broth media without fermentable carbohydrate was often 5.85 to 6.0 ; therefore, $\mathrm{pH} 5.7$ or above was interpreted as no fermentation, $\mathrm{pH}$ between 5.5 and 5.7 was interpreted as weak fermentation, and $\mathrm{pH}$ below 5.5 was interpreted as strong fermentation. In general, the terminal $\mathrm{pH}$ of cultures in broth media containing fermentable sugars was the same in an atmosphere of $90 \%$ nitrogen-10\% carbon dioxide as it was in $100 \%$ carbon dioxide.

Biochemical reactions. Some biochemical reactions of strain ATCC 29303 and of 13 other similar strains are given in Table 4 . The strains grew very poorly, if at all, in PYG-20\% bile broth or in PYG-6.5\% $\mathrm{NaCl}$ broth.

TABLE 4. Reactions of B. disiens, B. bivius, and 5 other strains of bacteroides studied.*

\begin{tabular}{|c|c|c|c|c|c|c|c|c|c|}
\hline \multirow[b]{2}{*}{ Reaction } & \multicolumn{2}{|c|}{ B. disiens } & \multicolumn{2}{|c|}{ B. bivius } & \multicolumn{5}{|c|}{ Unidentified strains of bacteroides } \\
\hline & $\begin{array}{l}\text { ATCC } \\
29426\end{array}$ & $\begin{array}{l}\% \text { pos. } \\
11 \text { strains }\end{array}$ & $\begin{array}{l}\text { ATCC } \\
29303\end{array}$ & $\begin{array}{c}\% \text { pos. } \\
14 \text { strains }\end{array}$ & 7620 & 9447 & 9754 & 10709 & 10879 \\
\hline \multicolumn{10}{|l|}{ Acid from: } \\
\hline Dextrin & $\mathrm{A}$ & 100 & A & 100 & A & $\mathrm{nt}$ & $n t$ & $n t$ & $\mathrm{nt}$ \\
\hline Fructose & A & 91 & A & 93 & - & A & A & A & A \\
\hline Galactose & - & 0 & A & 71 & - & nt & $\mathrm{nt}$ & nt & nt \\
\hline Glucose & $\mathrm{A}$ & 100 & $\mathrm{~A}$ & 100 & A & A & A & A & $\mathrm{A}$ \\
\hline Glycogen & $\mathrm{A}$ & 100 & $\mathrm{~A}$ & 100 & A & A & A & A & - \\
\hline Lactose & - & 0 & $\mathrm{~A}$ & 93 & $w$ & - & A & A & A \\
\hline Maltose & A & 100 & A & 100 & - & A & A & A & A \\
\hline Mannitol & - & 0 & - & 0 & - & - & - & - & - \\
\hline Mannose & - & 18 & A & 93 & A & A & A & - & $\mathrm{A}$ \\
\hline Starch & A & 100 & A & 100 & - & A & A & $\mathrm{A}$ & - \\
\hline Sucrose & - & 0 & - & 0 & - & A & - & - & - \\
\hline \multicolumn{10}{|l|}{ Digestion of } \\
\hline Gelatin & + & 100 & + & 100 & + & + & - & - & + \\
\hline Milk & + & 100 & + & 100 & + & + & - & - & - \\
\hline Casein & + & 100 & + & 100 & - & + & - & - & - \\
\hline Meat & + & 100 & + & 100 & + & + & - & - & - \\
\hline \multicolumn{10}{|c|}{ Hydrolysis of } \\
\hline Esculin & - & 0 & - & 0 & - & - & + & + & - \\
\hline Starch & + & 100 & + & 100 & + & + & + & + & - \\
\hline
\end{tabular}

${ }^{*}$ Symbols: -, Negative reaction; +, positive reaction; A, acid; w, weak acid ( $\mathrm{pH} 5.5-5.7$ ); nt, not tested. All strains were negative for fermentation of amygdalin, arabinose, cellobiose, erythritol, esculin, inositol, melezitose, melibiose, raffinose, rhamnose, salicin, sorbitol, trehalose, and xylose. No strain reduced nitrate or produced lecithinase or lipase (on egg yolk agar), indole, or catalase. 
Gelatin was usually completely digested after incubation for 2 days. Milk cultures usually developed a soft curd, which was subsequently digested. Obvious digestion of milk was often apparent within 3 days, although about $20 \%$ of the cultures required incubation for 2 weeks before digestion was certain. Meat was digested within 1 week, often within 1 to 3 days. Many freshly isolated strains did not digest milk and meat for 10 to 14 days, but casein digestion was usually apparent in $48 \mathrm{~h}$, even with freshly isolated strains.

Fermentation products. The fermentation acids (in average milliequivalents per $100 \mathrm{ml}$ ) from PYG cultures were succinic (5.2) and acetic (1.5) acids, usually with a trace of isovaleric acid, often with a trace of isobutyric acid, and occasionally with a small amount of lactic acid.

The products from CMC broth cultures were succinic $(11.2 \mathrm{meq} / 100 \mathrm{ml})$, acetic $(3.9 \mathrm{meq} / 100$ $\mathrm{ml}$ ), and isovaleric $(0.64 \mathrm{meq} / 100 \mathrm{ml})$ acids, usually with a small amount of isobutyric acid.

Lactate and pyruvate were not utilized.

Hydrogen was not produced; there were no, or only a few, gas bubbles in PYG agar deep cultures.

Resistance to antimicrobial agents. All strains were susceptile to chloramphenicol (12 $\mu \mathrm{g} / \mathrm{ml})$, clindamycin $(1.6$ and $3.2 \mu \mathrm{g} / \mathrm{ml})$, and erythromycin $(3 \mu \mathrm{g} / \mathrm{ml})$. Ten of 14 strains (71\%) were susceptible to tetracycline $(6 \mu \mathrm{g} / \mathrm{ml})$; only 4 of 14 were susceptible to penicillin $(2 \mathrm{U} / \mathrm{ml})$.

$\mathrm{G}+\mathrm{C}$ content. The $\mathrm{G}+\mathrm{C}$ content of the DNA was $40 \mathrm{~mol} \%$ for strain ATCC 29303 (= VPI 6822 ) and for four other strains tested.

Type strain. ATCC $29303 \quad(=$ VPI 6822 [Donna Blazevic, University of Minnesota, no. $653 \mathrm{C}$, isolated from endometrium]).

Strains of $B$. disiens and $B$. bivius do not

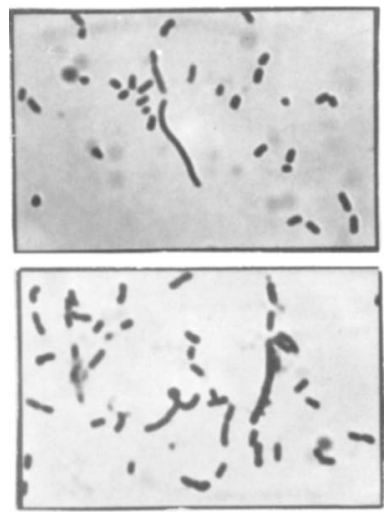

FIG. 2. Bacteroides bivius ATCC 29303. Left, Cells from 24-h-old peptone-yeast broth culture. Right, Cells from 24-h-old peptone-yeast-glucose broth culture. See Fig. 1 for scale. grow well in PYG-20\% bile broth or ferment sucrose, as do $B$. fragilis, $B$. thetaiotaomicron, $B$. vulgatus, $B$. distasonis, and $B$. ovatus (2). They are similar to $B$. oralis in many morphological and cultural characteristics; however, they differ by not fermenting sucrose or raffinose and by digesting milk and meat. $B$. disiens and $B$. bivius do not form black or brown colonies on blood agar, as do strains of B. melaninogenicus. They may, however, show some light orange to pink fluorescence on blood agar plates incubated for $48 \mathrm{~h}$, as do some of the saccharolytic strains of $B$. melaninogenicus. None, however, has been observed to show a brick red fluorescence. Characteristics useful in differentiating $B$. disiens and B. bivius from other saccharolytic bacteroides that do not grow well in bile are given in Table 5 .

Characteristically, strains of $B$. bivius ferment lactose and strains of $B$. disiens do not. However, one strain of $B$. bivius (VPI 7962) that showed $89 \%$ homology with DNA of $B$. bivius ATCC 29303 was phenotypically indistinguishable from strains of $B$. disiens. VPI 7962 consistently did not ferment galactose, lactose, or mannose and, in all respects tested, had phenotypic characteristics like strains of $B$. disiens. Two separate DNA preparations of VPI 7962 showed a high degree of homology with reference DNA of $B$. bivius and little homology with reference DNA of $B$. disiens. Phenotypic tests of 7962 were repeated several times, using a subculture of the culture used in the DNA preparations, and all results were as described.

Somewhat similar strains of Bacteroides (7620,9447, 9754, 10709, and 10879), listed as "unidentified" in Tables 1 and 2, showed negligible homology with the $B$. bivius and $B$. disiens reference DNAs. These strains produced succinic and acetic acids as major fermentation products, did not produce hydrogen, and did not grow in PYG-20\% bile broth. Major phenotypic differences between these strains and $B$. bivius and $B$. disiens were the lack of proteolytic activity $(9754,10709$, and 10879), absence of fermentation of starch (7620 and 10879), and fermentation of sucrose (9447).

There was no growth of any strain of $B . d i$ siens tested (ATCC 29426, VPI 9061, 9495, 9629) or of any strain of B. bivius tested (ATCC 29303, VPI $7962,8587,9498,9725,10207)$ in the fifth serial transfer in hemin-free PYG. Only three strains of $B$. disiens (VPI 9061, 9495, and 9629) grew in the third serial transfer of PYG-HF; VPI 9629 grew in the fourth serial transfer, but not in the fifth. B. disiens ATCC 29426 and $B$. bivius ATCC 29303 did not grow in the third serial transfer in the two different lots of PYG$\mathrm{HF}$ media tested at two different times. All 
TABLE 5. Some differential characteristics of B. disiens, B. bivius, and some similar species of Bacteroides ${ }^{a}$

\begin{tabular}{|c|c|c|c|c|c|c|c|}
\hline Species & $\begin{array}{l}\text { Indole } \\
\text { production }\end{array}$ & $\begin{array}{l}\text { Esculin } \\
\text { hydrolysis }\end{array}$ & Lactose & Starch & Sucrose & $\begin{array}{c}\text { Black } \\
\text { pigment }\end{array}$ & $\begin{array}{l}\text { Growth in } \\
20 \% \text { bile }\end{array}$ \\
\hline B. disiens & - & - & - & + & - & - & I \\
\hline B. bivius & - & - & + & + & - & - & I \\
\hline $\begin{array}{l}\text { B. melaninogenicus } \\
\text { subsp. intermedius }\end{array}$ & $\mathrm{v}$ & - & $\mathrm{v}$ & +- & $\mathrm{v}$ & + & I \\
\hline $\begin{array}{l}\text { B. melaninogenicus } \\
\text { subsp. melaninogenicus }\end{array}$ & - & +- & + & + & + & + & I \\
\hline B. oralis & - & + & + & + & + & - & I \\
\hline B. eggertbii & + & + & + & + & - & - & + \\
\hline
\end{tabular}

$a_{-}$, Negative reaction or no fermentation; + , positive reaction or fermentation; $v$, variable reaction; $I$, growth inhibited. Where two reactions are given, the first is the more usual and the second is observed less frequently.

strains grew well in the first transfer in PYG$\mathrm{HF}$, probably due to the hemin that was carried over in the CMC inoculum. All strains tested grew well in the third and fourth serial transfers in PYGH medium.

As has been reported for some other species of Bacteroides, $B$. disiens and $B$. bivius require hemin for growth. Gibbons and Macdonald (4) found that many strains of B. melaninogenicus, particularly the saccharolytic strains, require hemin for growth, and Caldwell et al. (1) reported that hemin was required by $B$. ruminicola. More recently, Macy et al. (12) reported that hemin stimulated growth of and succinate production by $B$. fragilis ATCC 23745 . They detected a $b$-type (and possibly a $c$-type) cytochrome and a fumarate reductase in cells grown with hemin, but not in cells grown without hemin, and postulated that adenosine 5 '-triphosphate generated during reduction of fumarate to succinate could be responsible for the increased growth rate and cell yield in hemincontaining media. Although Macy et al. did not report an absolute hemin requirement for growth of $B$. fragilis, an absolute requirement has been found for strains of $B$. fragilis (M. D. Appleman, J. L. Johnson, and T. D. Wilkins, Bacteriol. Proc., p. 132, 1976).

\section{ACKNOWLEDGMENTS}

We gratefully acknowledge the technical assistance of Luba Fabrycky, Ann Mitchell, Habiba Najafi, Carol Phelps, and Sue Smith. This research was supported by Public Health Service Grant GM-14604 from the National Institute of General Medical Sciences.

\section{REPRINT REQUESTS}

Address reprint requests to: Dr. Lillian V. Holdeman, Anaerobe Laboratory, College of Agriculture and Life Sciences, Virginia Polytechnic Institute and State University, Blacksburg, VA 24061.

\section{LITERATURE CITED}

1. Caldwell, D. R., D. C. White, M. P. Bryant, and R. N. Doetsch. 1965. Specificity of the heme requirement for growth of Bacteroides ruminicola. J. Bacteriol. 90:1645-1654.

2. Cato, E. P., and J. L. Johnson. 1976. Reinstatement of species rank for Bacteroides fragilis, B. ovatus, B. distasonis, B. thetaiotaomicron, and B. vulgatus. Designation of the neotype strains of Bacteroides fragilis (Veillon and Zuber) Castellani and Chalmers and Bacteroides thetaiotaomicron (Distaso) Castellani and Chalmers. Int. J. Syst. Bacteriol. 26:230-237.

3. Cummins, C. S., and J. L. Johnson. 1971. Taxonomy of the clostridia: wall composition and DNA homologies in Clostridium butyricum and other butyric acid-producing clostridia. J. Gen. Microbiol. 67:33-46.

4. Gibbons, R. J., and J. B. Macdonald. 1960. Hemin and vitamin $\mathrm{K}$ compounds as required factors for the cultivation of certain strains of Bacteroides melaninogenicus. J. Bacteriol. 80:164-170.

5. Holdeman, L. V., and W. E. C. Moore. 1974. Family I. Bacteroidaceae Pribram 1933, 10, p. 384. In R. E. Buchanan and N. E. Gibbons (ed.), Bergey's manual of determinative bacteriology, 8th ed. The Williams and Wilkins Co., Baltimore.

6. Holdeman, L. V., and W. E. C. Moore. (ed.). 1975. Anaerobe laboratory manual, 3rd ed., p. 9, 27-37, 101-128. Anaerobe Laboratory, Virginia Polytechnic Institute and State University, Blacksburg, Va.

7. Johnson, J. L. 1973. The use of nucleic acid homologies in the taxonomy of anaerobic bacteria. Int. J. Syst. Bacteriol. 23:308-315.

8. Johnson, J. L., and C. S. Cummins. 1972. Cell wall composition and deoxyribonucleic acid similarities among the anaerobic coryneforms, classical propionibacteria, and strains of Arachnia propionica. J. Bacteriol. 109:1047-1066.

9. Johnson, J. L., and E. J. Ordal. 1968. Deoxyribonucleic acid homology in bacterial taxonomy: effect of incubation temperature on reaction specificity. J. Bacteriol. 95:893-900.

10. Lambe, D. W., Jr., and D. A. Moroz. 1976. Serogrouping of Bacteroides fragilis subsp. fragilis by the agglutination test. J. Clin. Microbiol. 3:586-592.

11. Lambe, D. W., Jr., and R. C. Jerris. 1976. Description of a polyvalent conjugate and a new serogroup of $\mathrm{Bac}$ teroides melaninogenicus by fluorescent antibody staining. J. Clin. Microbiol. 3:506-512.

12. Macy, J., I. Probst, and G. Gottschalk. 1975. Evidence 
for cytochrome involvement in fumarate reduction and adenosine 5 -triphosphate synthesis by Bacteroides fragilis grown in the presence of hemin. J. Bacteriol. 123:436-442.

13. Marmur, J. 1961. A procedure for the isolation of deoxyribonucleic acid from micro-organisms. J. Mol. Biol. 3:208-?18.

14. Marmur, J., and P. Doty. 1962. Determination of the base composition of deoxyribonucleic acid from its ther- mal denaturation temperature. J. Mol. Biol. 5:109-118.

15. Moore, W. E. C., and L. V. Holdeman. 1974. Human fecal flora: the normal flora of 20 Japanese-Hawaiians. Appl. Microbiol. 27:961-979.

16. Wilkins, T. D., and T. Thiel. 1973. Modified broth-disk method for testing the antibiotic susceptibility of anaerobic bacteria. Antimicrob. Agents Chemother. 3:350-356. 